CALEIDOSCOPIO

21

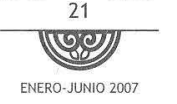

Las ejecuciones selectivas del Ejército Revolucionario del Pueblo: nociones implicadas en el ejercicio de la justicia revolucionaria

VERA CARNOVALE/

Universidad de Buenos Aires (UBA)

Consejo Nacional de Investigaciones Cientificas y Técnicas (CONICET)

“...el arma de un combatiente es su humanidad.

Porque, en los primeros momentos de la rebelión, hay que matar: matar a un europeo es matar dos pájaros de un tiro, suprimir a la vez a un opresor y a un oprimido: quedan un hombre muerto y un hombre libre". Jean-Paul Sartre

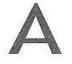

partir de la década de 1950, la experiencia de distintos procesos revolucionarios y emancipatorios del Tercer Mundo ofrecieron al ambiente de las izquierdas nuevas significaciones en relación con el uso de la violencia en la prosecución del cambio revolucionario. Quedaba claro, en principio, que dicho cambio era posible aún en sociedades donde el capitalismo industrial no había alcanzado su madurez; pero más importante aún, tras el aporte del guevarismo, el tiempo de espera de las llamadas "condiciones subjetivas" quedaba arrasado por
\end{abstract}

1 En Franz Fanon, Los condenados de la tierra, México, FCE, 1963, p. 20. 
la urgencia de las voluntades, puesto que la acción de los revolucionarios podía crearlas. Y esa acción, se entendía, llevaba el signo de la violencia; de una violencia nueva, necesaria: "ninguna dulzura borrará las señales de la violencia; sólo la violencia puede destruirlas"2. Se trataba de una violencia emancipadora, destructora de la opresión y creadora de un nuevo orden y de "hombres nuevos"; el oprimido "hijo de la violencia, en ella encuentra a cada instante su humanidad...", advertía Sartre ${ }^{3}$. Una violencia que, para muchos, llevaba el sello del sacrificio de sangre.

Diversas experiencias de insurgencia armada - que se habían evidenciado exitosas- alimentaron debates y constituyeron modelos ejemplares para distintas organizaciones revolucionarias que, en nombre de los aplastados por el hambre y el poder, se lanzaban al combate.

En los imaginarios en conformación, las tradicionales representaciones insurreccionales de la revolución fueron acompañadas en algunos casos, desplazadas en otros, por palabras y símbolos del foco y de la guerra.

Este nuevo escenario se conjugó en Latinoamérica con un cristianismo postconciliar radicalizado que proponía, como parte de un compromiso ineludible con los pobres y la humanidad, oponer a la "violencia institucionalizada" de la opresión una de nuevo tipo, revolucionaria y liberadora. Y como ejemplo e icono de ese compromiso, se erigía la figura de Camilo Torres, el "cura guerrillero".

En Argentina, desde la cárcel de Villa Devoto en 1969, Juan García Elorrio, director de la revista Cristianismo y Revolución de gran influencia en los círculos militantes, exclamaba: "¿Es necesario repetir que estamos en tiempo de guerra? El combate liberador se libra en todos los frentes, en todas las naciones, en toda la humanidad [...] Nuestro deber como cristianos y revolucionarios es asumir nuestro compromiso total con esta lucha de liberación [...] iPorque ya llega el día de la matanza!"4

2 Jean Paul Sartre, en Fanon op. cit., p. 20

3 En Fanon, op cit., p. 22.

4 "Teología para el Tercer Mundo. Los cristianos, la violencia y la revolución", en Cristianismo y Revolución, Buenos Aires, 1969, p. 12. La frase final corresponde a un párrafo bíblico (Santiago 5, 1-5) con el que se abre su texto "Advertencia". 
Los grupos armados locales surgidos a partir de la dictadura encabezada por el General Onganía ${ }^{5}$, entre ellos el PRT-ERP 6 , se nutrieron, en gran medida, de estos torrentes que invitaban a asistir con nuevas prácticas y sentidos a la partera de la historia. En su imaginario, en las connotaciones y sentidos más profundos de sus formulaciones político-ideológicas, quedaron anudados con lazo indisoluble, violencia e historia, sacrificio y hombre nuevo, guerra y revolución. Y en ese lazo que fundía la sangre con el porvenir, morir y matar remitían al tiempo nuevo de la emancipación definitiva del hombre. Y en consecuencia, quienes se integraron a sus filas en prosecución de la consagración histórica, ofrendaron sus vidas y, también, mataron.

En el amplio abanico de sus prácticas políticas y militares el PRT-ERP incluyó la ejecución selectiva de personas. El presente trabajo intenta echar luz sobre las circunstancias, nociones y sentidos epocales que sustentaron las ejecuciones perretistas ${ }^{7}$.

$5 \quad$ El golpe de Estado encabezado por el general Onganía en junio de 1966 instauró una dictadura militar que habría de durar hasta mayo de 1973. Durante ese lapso se sucedieron en el poder los generales: Juan C. Onganía (1966-1970), Marcelo Levingston (1970 1971) y Agustín Lanusse (1971-1973)

6 El PRT-ERP fue una organización armada de la izquierda revolucionaria argentina. En 1965 tuvo lugar la fundación del Partido Revolucionario de los Trabajadores (PRT) a partir de la confluencia entre el Frente Revolucionario Indoamericano Popular (FRIP), movimiento indoamericanista liderado por Mario R. Santucho y Palabra Obrera, agrupación trotskista liderada por Nahuel Moreno. Tras la escisión de esta última organización en 1968, el PRT decidió incluir en lo inmediato la lucha armada en su estrategia para la toma del poder y fundó, en 1970, su brazo armado, el Ejército Revolucionario del Pueblo (ERP). Durante los primeros años de la década de 1970 el PRT-ERP se erigió como la principal organización armada marxista. A partir de julio de 1976 sus principales referentes y la mayor parte de sus militantes fueron muertos, encarcelados o partieron al exilio.

7 "Perretista" significa "del PRT". Aunque la mayoría de las acciones analizadas en el presente trabajo hayan sido llevadas a cabo por el ERP (en tanto brazo armado del PRT), se utilizará aquí la expresión "perretista" para hacer referencia a las prácticas, ideas, militancia etc. de dicha organización armada.
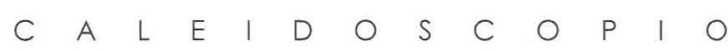


\section{LOS EJECUTADOS}

Este trabajo se basa en un conjunto inicial de 58 casos de personas ejecutadas por el ERP entre marzo de 1972 y febrero de 1977. Han quedado excluidas de ese conjunto las muertes producidas en combates abiertos, en asalto a guarniciones militares o comisarías, aquellas que resultaran de enfrentamientos armados inesperados (desarmes a policías, fuga de prisioneros, controles policiales, etc.). Tampoco se han tenido en cuenta aquellos atentados perpetrados por el ERP en los que las víctimas resultaron ilesas o heridas. Los 58 casos se han reagrupado en tres:

CASO A: son aquellos que evidencian un alto grado de selectividad. Se trata de personas ejecutadas o bien en acciones que tenían como principal objetivo, precisamente, dicha ejecución o bien de personas secuestradas por el ERP cuya ejecución estaba prevista en caso de fracaso de la negociación correspondiente o de un eventual enfrentamiento inesperado con las fuerzas represivas. Los casos tipo "A" suman un total de 37.

CASO B: se incluyen aquí aquellas muertes por las que el ERP asume cierta responsabilidad pero que no estaban particularmente planificadas; es decir que la ejecución de la persona no constituía el objetivo de la acción. Estos casos evidencian un nivel ínfimo -o nulo- de selectividad. Se trata, en general, de eventos en las que la víctima opone "resistencia" ante un desarme o cualquier otra acción del ERP, resistencia que "obliga a los combatientes a disparar". Los casos tipo "B" suman un total de 6.

CASO DUDOSOS: se han agrupado bajo este rótulo a aquellas muertes que dan lugar a serias dudas o bien en cuanto a la autoría de las mismas o bien en cuanto a su naturaleza (por ejemplo, aquellos casos en los que se encontraron distintos relatos de los hechos y que, según qué relato se considere se trataría de ejecuciones sumarias, muertes en combate, muertes ante "resistencias" o suicidios). Los casos "DUDOSOS" suman un total de 15.

Sobre este primer agrupamiento resulta fecundo delinear otro a partir de categorías que identifican a las personas ejecutadas en tanto actores socio-políticos específicos. En este segundo agrupamiento, del total inicial de 58 casos: 
- 34 corresponden a integrantes de las fuerzas represivas legales o ilegales: miembros de las Fuerzas Armadas, de la Policía Federal y las policías provinciales, integrantes de grupos paraestatales o de los servicios de inteligencia;

- 15 corresponden a empresarios y personal jerárquico de diversas empresas;

- 5 corresponden a un conjunto heterogéneo conformado por: un militante del ERP condenado por "traidor" y cuatro "delatores" y/o "colaboradores" del Ejército en Tucumán";

- 2 corresponden a sindicalistas;

- 2 corresponden a casos "dudosos" de personas que, además, no pertenecen a ninguna de las anteriores categorías.

Cruzando los dos tipos de agrupamientos, obtenemos el siguiente cuadro:

\begin{tabular}{|l|c|c|c|c|}
\hline & $\begin{array}{c}\text { Casos } \\
\text { A }\end{array}$ & $\begin{array}{c}\text { Casos } \\
\text { B }\end{array}$ & $\begin{array}{c}\text { Casos } \\
\text { DUDOSOS }\end{array}$ & Totales \\
\hline Fuerzas represivas & 20 & 5 & 9 & 34 \\
\hline Sectores empresariales & 10 & 1 & 4 & 15 \\
\hline $\begin{array}{l}\text { Infiltrados, traidores y } \\
\text { colaboradores }\end{array}$ & 5 & - & - & 5 \\
\hline Sindicalistas & 2 & - & - & 2 \\
\hline Otros & - & - & 2 & 2 \\
\hline Totales & 37 & 6 & 15 & 58 \\
\hline
\end{tabular}

Una primera mirada sobre estos datos nos permite afirmar que el blanco privilegiado de las ejecuciones del ERP estuvo compuesto por integrantes de las fuerzas represivas y, en segundo término, por empresarios o ejecutivos de empresas.

Provincia del norte argentino en la que el ERP estableció un foco guerrillero en 1974. 
Teniendo en cuenta que uno de los componentes del universo de referencias al que apeló la agrupación guerrillera en su proceso de construcción identitaria fue la figura del "enemigo", resulta pertinente apuntar que las ejecuciones se correspondían con las acepciones del concepto de "enemigo" presentes en la discursividad partidaria. En ella convivían dos acepciones. Una se vinculaba con definiciones teórico-ideológicas: "el enemigo" aparecía asociado a la estructura de poder económico, era, en definitiva, un enemigo de clase. En la otra acepción, el "enemigo" aparecía directamente identificado con los agentes represores del Estado, especialmente con las Fuerzas Armadas. Es esta última acepción la que terminaría imponiéndose sobre la primera 9 . Ahora bien, en tanto dentro de ese vasto conjunto, no todo "enemigo" se constituyó en blanco de una ejecución resulta fructífero atender a los motivos esgrimidos ante las mismas a la hora de dar cuenta del esquema de valores y sentidos sobre los que éstas se sustentaron.

Las primeras ejecuciones selectivas del ERP datan de los meses de marzo y abril del año $1972^{10}$. Como ya ha sido señalado, entre esa fecha y febrero de 1977 se registraron un total de 37 ejecuciones con un alto índice de selectividad. Tomando únicamente los casos de integrantes de las fuerzas represivas y empresarios se advierte que dichas ejecuciones se sustentaron sobre el móvil de la represalia. Ésta conjugaba componentes propios de una cultura de la venganza con nociones y valores de una justicia sustantiva, "popular" o "revolucionaria" que, se advertía, iría reemplazando poco a poco a la del régimen. De ahí, la palabra "ajusticiamiento" con que la organización denominó estas acciones (volveremos sobre estas nociones en los apartados siguientes).

A partir de las declaraciones públicas formuladas tras las ejecuciones de empresarios y represores se puede constatar que los conside-

Confrontar con Vera Carnovale, "El concepto del enemigo en el PRT-ERP", en Lucha Armada en la Argentina, año 1, No 1, Buenos Aires, 2004, pp. 4-11.

10. Éstas fueron: las del Comandante Principal Abel P. Agarotti, ejecutado el 17-03; la del director general de FIAT, Oberdan Sallustro, secuestrado el 21-03 y ejecutado el 10-04; y la del Gral. Juan C. Sánchez, comandante del Il cuerpo de Ejército, ejecutado también el 10-04. 
rados crímenes en respuesta de los cuales el ERP ejecutó la sentencia de pena de muerte pueden ser agrupados en dos:

1) responsabilidad o culpabilidad directa respecto de situaciones específicas de injusticia social (explotación, despidos, bajos salarios, etc.) e instigamiento y/o complicidad con la actividad represiva en el movimiento obrero.

2) responsabilidad o culpabilidad directa en torturas y asesinatos de militantes "del campo popular" en general y combatientes del ERP en particular.

\section{A: EMPRESARIOS}

De los 10 empresarios ejecutados selectivamente, al menos 6 lo fueron en virtud del primer tipo de delitos. Estos fueron los casos de: Oberdan Sallustro, director general de la FIAT (10-04-72), Ramón Samaniego, jefe de personal de La Cantábrica (04-12-74), Héctor Minetti, presidente de la Cámara de Cemento Pórtland Sudamericana y de la Compañía Juan Minetti e Hijos (28-02-76), Miguel Salizotsky, jefe de seguridad industrial del Frigorífico Swift (28-05-76), Adolfo Valis, vicecomodoro retirado y gerente de personal de La Cantábrica (09-11-76), Pedro Lombardero, gerente de relaciones laborales de TAMET (10-02-77).

Resulta particularmente difícil deshilvanar la trama de sentidos y circunstancias que determinaron la ejecución de cada uno de estos empresarios. En principio, sería apresurado considerar estas ejecuciones como derivaciones necesarias de nociones de justicia revolucionaria preestablecidas. En ellas, encontramos que la pena de muerte se correspondía más con la figura del represor que con la del empresario, cuyos delitos podían ser "pagados" mediante otros medios: "es justicia popular la acción de ajusticiar a un torturador, de secuestrar a un explotador y sacarle aunque más no sea una parte de las riquezas que día a día nos roba" "1!; "así se irán enterando quienes se hacen los desentendidos, porque ejecutaremos a los asesinos del

Estrella Roja No 23, 15-08-73, p. 5. Estrella Roja era el órgano de propaganda del ERP. 
pueblo, llevaremos a la cárcel a quienes lo explotan y persiguen"12

Conviene señalar al mismo tiempo, en relación con lo anterior, que no parece haber sido la ejecución sino el secuestro extorsivo la práctica más frecuente del ERP en relación con el sector empresarial ${ }^{13}$. Estos secuestros, pueden ser inscriptos en el orden de un imaginario justiciero (al igual que la expropiación y repartos de alimentos) puesto que ofrecían la posibilidad de hacer efectiva la reparación al menos parcial -y en gran medida particularizada- del daño cometido, al tiempo que le permitían a la organización erigirse ante las masas y ante sí misma como autora y referente de pequeños actos de reversión de injusticias. De ahí que gran parte de las exigencias ante cada secuestro incluyera el reparto de bienes de primera necesidad a los trabajadores de la empresa, mejoras en sus condiciones laborales, reincorporación de cesanteados y una suma importante de dinero que, de esa manera, le era "restituida" al pueblo a través de su vanguardia. Había, además, un componente al menos retóricamente presente en esa escena justiciera y que la organización no dejaba de resaltar: la realización, con pocos recursos, de una hazaña "limpia", esto es, sin hechos de sangre. Y en eso radicaba el carácter ejemplar de estas acciones: los revolucionarios venían a demostrar a través de pequeños actos en qué consistía un orden socialmente justo.

El secuestro de Oberdan Sallustro podría haber sido una más de aquellas acciones "exitosas" y espectaculares, (como había sido un año antes el secuestro del gerente del Frigorífico Swift, Stanley Silvester ${ }^{14}$ ). Sin embargo, no lo fue.

Tras secuestrarlo el 21-03-72, la justicia perretista declaró a Sallustro "culpable y autor responsable de maniobras monopolistas perpetuadas por Fiat en perjuicio de la república Argentina, culpable e instigador

12 Estrella Roja No 12, marzo/abril de 1972, reproducida en De Santis, A vencer o morir. PRT-ERP documentos, tomo I, Buenos Aires, Eudeba, 1998, p. 315.

13 Las FFAA han computado 98 casos de secuestros extorsivos denunciados entre 1971 y 1976. De ese total, se presume que aproximadamente la mitad corresponderían al ERP.

14 Secuestrado por el ERP el 23-05-71 y liberado días después tras el éxito en las negociaciones con la empresa. 
responsable de la represión efectuada [... a a la planta industrial de Córdoba en septiembre de 1971 y culpable y autor responsable de la desocupación y miseria ocasionada por los despidos de más de 500 trabajadores de la planta...La pena que le corresponde en razón de su culpa es la pena de muerte" 15 . Pero esta pena de muerte, a diferencia de la que pesó sobre reconocidos torturadores (que, según las propias advertencias perretistas, serían ejecutados "en el lugar donde se los encontrara" ${ }^{16} \sin$ mediar negociación alguna), podía quedar sin efecto. Para ello y para dejar en libertad al empresario el ERP exponía siete condiciones entre las que se destacaban: la liberación de los obreros detenidos en el mencionado conflicto, la reincorporación de los cesanteados, una indemnización "al pueblo" (en forma de repartos de víveres y útiles escolares), una al ERP (que se pactó en un millón de dólares) y aquella que finalmente obstaculizaría las negociaciones, la liberación y el traslado al exterior de 50 guerrilleros presos, varios de ellos miembros de la dirección partidaria, entre ellos, Santucho ${ }^{17}$.

Si el cumplimiento de gran parte de estas exigencias estaba en manos de la empresa -que se mostró dispuesta a concederlas- la liberación de los presos políticos era una decisión que sólo la dictadura podía tomar pero que en ese punto se mostró inflexible ${ }^{18}$. Por su parte, era precisamente ésa la condición primordial para el ERP que, pasando por alto la disparidad de intereses y eventuales costos de unos

15 Comunicado de prensa del 24-03-72, reproducido en In Memoriam (1999), tomo III, p. 115.

16 Fórmula corriente empleada por el ERP en sus anuncios de condena a muerte de determinados represores. Véase, por ejemplo, "El pueblo castiga a sus torturadores" en Estrella Roja No 23, 15-08-73

$17 \mathrm{Al}$ igual que para otras organizaciones guerrilleras de distintas partes del mundo, la liberación de presos de las propias filas (y, más tarde, ante el feroz recrudecimientos de la actividad represiva ilegal, !a exigencia de garantías de vida y de integridad física) constituyó un reclamo constante en las distintas negociaciones que el ERP mantuvo principalmente con las Fuerzas Armadas. Desde el punto de vista de la subjetividad colectiva, esto contribuía no sólo al afianzamiento del sentido de pertenencia a la organización sino también al fortalecimiento de lazos simbólicos entre los militantes.

18 Confrontar con María Seoane, Todo o nada. La historia secreta y la historia pública del jefe guerrillero Mario Roberto Santucho, Buenos Aires, Planeta, 1991.
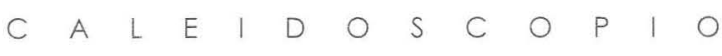
y otros, aguardó a que Estado y capital respondieran conjuntamente ante la "justicia popular". No lo hicieron. Fracasadas las negociaciones y en momentos en que las fuerzas represivas detectaron y rodearon la "cárcel del pueblo" donde permanecía secuestrado, Sallustro fue ejecutado.

Su ejecución sin embargo, aunque probablemente prevista en determinadas circunstancias como las que finalmente se precipitaron, fue presentada por la prensa partidaria como responsabilidad de la "dictadura militar [que] poniendo una vez más en evidencia, que nada le importa la vida humana con tal de salvaguardar sus intereses económicos, prefirió sacrificarlo; no negoció, siguió su insensata política represiva y obligó a nuestros combatientes a ajusticiar a Sallustro, tal como lo habíamos advertido"19.

Esta suerte de autoexculpación pública por la ejecución del empresario, el tono y las palabras escogidas (ellos, en su desprecio de la vida humana lo sacrificaron, nosotros nos vimos obligados a ajusticiarlo), tan distintas de las declaraciones a través de las cuales se solían anunciar y reivindicar los "ajusticiamientos", permiten pensar en cierta incomodidad ante esta muerte. Es plausible postular que la misma haya sido un acto de precipitación ante circunstancias no deseadas, pero en absoluto ajenas al error de cálculo propio en la medición de fuerzas en negociación, a la voluntad de demostrarle a una dictadura en creciente crisis de legitimidad el poder de una guerrilla que se sabe en ascenso $\mathrm{y}$, en consecuencia, al intento obstinado por imponer las reglas del juego. La insistencia retórica en una ética militante inquebrantable que impedía dar marcha atrás sobre los propios actos y palabras (aún en una "negociación"), hizo el resto.

En refuerzo de lo anterior se constata que tras la de Sallustro no se registraron otras ejecuciones (de empresarios) hasta más de dos años y medio después.

En diciembre de 1974 -en el contexto de una crisis política e institucional que comenzaba a evidenciarse insalvable signada, entre otras

19 "El largo brazo de la justicia popular", en De Santis, A vencer o morir. PRT-ERP documentos tomo I, Buenos Aires, Eudeba, 1998, p.316. 
cosas, por las luchas intestinas del peronismo, la persistencia de la protesta obrera, la intensificación del accionar represivo de la Triple $\mathrm{A}^{20}$ y una también creciente actividad guerrillera ${ }^{21}$ - el ERP "ajustició" a cuatro empresarios.

Exceptuando el caso del empresario pesquero Antonio Do Santos Larangueira para el que no contamos con la declaración perretista, se observa que sólo la ejecución de Samaniego, jefe de personal de La Cantábrica, obedece al primer tipo de delitos mencionados anteriormente, en tanto las de Alberto Abeigon y Manuel Martínez, gerente general y gerente de personal respectivamente de la firma MILUZ, ejecutados el 30 de diciembre, corresponden al segundo grupo (su postulada responsabilidad en la muerte de militantes obreros). No obstante lo anterior, las tres ejecuciones responden a una misma voluntad rectificadora.

El "ajusticiamiento" de Samaniego (4-12-74) se presentó públicamente "como respuesta a la política represiva que viene llevando adelante la patronal explotadora, tratando de intimidar a sus obreros por medio de matones que los amenazan o como ocurrió con el compañero Leal, delegado de Sección que fue víctima de un atentado con una bomba"22. El énfasis en la actividad represiva de la patronal y el hecho de que esta ejecución haya tenido lugar en medio de una represalia "indiscriminada" contra las Fuerzas Armadas (declarada por el ERP en septiembre de 1974 como respuesta al fusilamiento de un grupo de guerrilleros en la provincia de Catamarca), permiten suponer que el punto neurálgico de la sensibilidad perretista que daba origen a la "respuesta" remitía menos al lugar y responsabilidad de la víctima

20 Triple A o AAA: Alianza Anticomunista Argentina. Organización parapolicial de ultraderecha fundada durante el tercer gobierno peronista (1973-1976). Se le atribuyen alrededor de 500 asesinatos durante ese período.

21 En septiembre de ese año Montoneros (organización político militar peronista) había pasado a la clandestinidad y retomado la actividad armada; al tiempo que hacia mediados de ese año el ERP instaló un foco guerrillero en el monte tucumano, la "Compañía del Monte Ramón Rosa Jiménez") .

"Ajusticiamiento", fuente original incluida en El terrorismo en la Argentina. Buenos Aires, Poder Ejecutivo Nacional, 1979, p. 323 
en un orden social que se percibía como injusto que a las prácticas represivas desatadas en el seno de las empresas en complicidad con las fuerzas estatales y paraestatales. Es porque "las bandas fascistas (militares y policías) están apoyadas y patrocinadas por las patronales explotadoras que en su desesperación de frenar las justas luchas obreras no vacilan en perseguir y atentar contra la vida a los trabajadores [quel recaerá sobre ellas todo el peso de la justicia revolucionaria"23.

La ejecución en represalia busca un efecto ejemplificador y rectificador. La ofensa por la que responde ha roto alguna regla o norma establecida real o imaginariamente. Desde la óptica perretista, que el burgués, en el transcurso de la lucha de clases, defendiera con todos los medios a su alcance sus propios intereses era tan esperable como inevitable. La condición de la explotación, se sabía, no radica en la existencia del burgués en sí sino en la perpetuación del orden capitalista. El endurecimiento de esta defensa en el transcurso de la "agudización" del conflicto de clases manifestada, por ejemplo, a través de despidos y represión de huelgas, constituía una conducta previsible. Formaba parte, por decirlo de otro modo, de las reglas del juego y de ahí que aquellas manifestaciones hayan sido percibidas como materia de "negociación". Pero lo que a los ojos de los revolucionarios había roto aquella normatividad tácita era la irrupción en escena de "bandas de matones" que, desde la ilegalidad de un orden ya de por sí injusto y violento, se cobraban en vidas el desafío obrero, sobre todo a partir de 1974.

\footnotetext{
"Ajusticiamiento", op. cit. La ejecución del sindicalista Antonio Magaldi (04-04-74) obedece al mismo esquema. En su declaración pública el ERP denunciaba que Magaldi "ha sido uno de los principales responsables del permanente ataque, persecución y vejámenes que sufren los trabajadores [...] por parte de las bandas de matones fascistas, armados por la burocracia sindical, por los directivos y dueños de las grandes empresas, por el ejército y la policía [... Frente a los crímenes de las bandas fascistas y parapoliciales, brazo armado de los opresores, el brazo armado del pueblo responde con la ejecución de Antonio Magaldi..." ("EL ERP AL PUEBLO" en Estrella Roja No 32, 10-04-74, Colección Documento Histórico No 29 de Infobae, p. 16).
} 
Las ejecuciones de los ejecutivos de la empresa MILUZ, Abeigon y Martínez, fueron la respuesta perretista "a los asesinatos de dos obreros de esa fábrica, Jorge Fisher y Miguel Bufano, muertos en este mes por las ya tristemente célebres "Tres A", brazo armado de las patronales"24. Y para que no quedaran dudas de la responsabilidad empresaria en el accionar de la organización parapolicial, el ERP la denunciaba en la explicación de su represalia: "¿Por qué el brazo de la justicia popular se abatió sobre dos miembros de la clase explotadora? |... Son ellos, los patrones, quienes pagan a los mercenarios que alquilan su brazo y su conciencia" 25

Estos "ajusticiamientos" buscaban, a través del castigo ejemplar, la rectificación de esa modalidad represiva que involucraba la vida de los activistas. De ahí, que las declaraciones públicas sobre las ejecuciones realizadas no sólo refirieran al tiempo pasado del crimen sino que incluyeran la advertencia sobre el accionar futuro: "La justicia revolucionaria, el terror revolucionario, que nace y se aumenta en el odio de clase contra nuestros explotadores y sus lacayos, [...] alcanzará implacablemente no sólo a quienes apuntan el arma y oprimen el gatillo, sino también -y principalmente- a quienes eligen el blanco y proporcionan los fondos para la cruzada contrarrevolucionaria $\mid$... |"26

En la cultura perretista los delitos de explotación propios de la condición de clase del burgués podían "negociarse", la sangre derramada no. Ante el crimen del asesinato sólo había lugar para un castigo equivalente. Al terror de la Triple A, el ERP buscó responder, entonces, con el "terror revolucionario"; a la muerte de dos militantes populares, con la de dos miembros de la patronal. Terror por terror, muerte por muerte.

El año siguiente a los "ajusticiamientos" de Larangueira, Samaniego, Abeigón y Martínez estuvo determinado, en sentido exactamente

\footnotetext{
24 "MILUZ: Iusticia Revolucionaria" en Estrella Roja No 47, 13-01-75. En De Santis, A vencer o morir. PRT-ERP documentos Tomo II, Buenos Aires, Eudeba, 2000, pp. 336337.

25 "Responder al terror con la justicia revolucionaria", editorial de Estrella Roja No 47. 13-01-75, Colección Documento Histórico No 16 de Infobae, p. 2.

26 Ídem anterior. El resaltado es mío.
} 
opuesto a las expectativas perretistas, por un sensible "reflujo" o repliegue de la movilización de masas y un acelerado recrudecimiento de la actividad represiva legal e ilegal. Para el ERP en particular, fue el período que determinó su derrota militar, no sólo por las desventuras de la Compañía del Monte en Tucumán y el trágico fracaso del asalto al cuartel de Monte Chingolo27, sino además por el desbaratamiento cotidiano de gran parte de sus estructuras operativas y el consecuente saldo de prisioneros, muertos y desaparecidos.

Fue también el período que selló su propio fracaso político -que en rigor precedió al militar- algunos de cuyos componentes fueron una completa ceguera y/o negación del mencionado repliegue y una pobreza creciente tanto en sus estrategias de activación de masas como en sus respuestas ante el avance de la represión.

En las diezmadas y desarticuladas estructuras de la organización perduraron, sin embargo, como antecedentes de referencia (y quizás, también, como formas del "sentir" la justicia revolucionaria) la práctica de las ejecuciones sumarias. Y aquellos componentes asimilables a una cultura de la venganza, en el contexto de una sensible retracción de acciones colectivas, contribuyeron finalmente a la solidificación definitiva de una "guerra de aparatos" en la que el ERP quedó entrampado y sólo podía perder.

Es precisamente en el marco de esa obstinada -y desesperada- guerra de aparatos que tienen lugar las ejecuciones de: Luis Doménech, ejecutivo de la compañía Isaura, secuestrado el 12-08-75 y ejecutado el 12-09 de ese mismo año; Héctor Minetti, presidente de la Cámara de Cemento Pórtland Sudamericana y de la Compañía Juan Minetti e Hijos, ejecutado el 28-02-76; Miguel Salizotsky, jefe de Seguridad Industrial del Frigorífico Swift, ejecutado el 28-05 del mismo año, Adolfo Valis, vicecomodoro (re) y gerente de personal de La Cantábrica, ejecutado el 9-11 y Pedro Lombardero, gerente de relaciones laborales de TAMET, ejecutado el 10-02-77.

27 El 23-12-75 el ERP intentó tomar una guarnición del Ejército situado en la localidad de Monte Chingolo, al sur de la ciudad de Buenos Aires. El intento terminó en una matanza ya que el Ejército estaba alertado sobre la operación por un infiltrado. La acción dejó un saldo aproximado de 80 bajas guerrilleras entre muertos y desaparecidos. 
A excepción del caso de Minetti, no se lee en las declaraciones partidarias mención alguna a crímenes de sangre por los que el ERP estuviera "ajusticiando" en represalia ${ }^{28}$. Se encuentran, más bien, fórmulas repetidas de la retórica partidaria, vinculadas, todas ellas, a la propia condición de clase de las víctimas.

Salizotsky, fue ejecutado, "por ser fiel defensor de la patronal del frigorífico" ${ }^{29}$; Valis, porque "cumplió hasta el final su misión de defender los intereses de la patronal explotadora, a costo del hambre y miseria de nuestro pueblo trabajador"; y casi como un reflejo mecánico, se advertía en este caso "a la patronal y a sus perros guardianes, las Fuerzas Armadas Contrarrevolucionarias, que de continuar sus atropellos y arbitrariedades, caerá sobre sus espaldas el largo brazo de la justicia popular...." 30

Finalmente, en el caso de Lombardero, el último empresario ejecutado por el ERP, se dejan oír los ecos de aquel punto neurálgico de la sensibilidad perretista que mencionáramos anteriormente: "...uno de los más fieles ejecutores de los planes represivos implementados por los explotadores de TAMET $y$ responsable directo del despido de 26 compañeros" ${ }^{\prime 31}$.

Suponiendo un grado importante de autonomía de los comandos que llevaron a cabo estas acciones (y esto por el ya mencionado pro-

28 En realidad tampoco lo hace el "Parte de guerra del ERP" que anuncia el "ajusticiamiento" de Minetti. En éste sólo se advierte que "Minetti había amasado fortunas con el sudor de miles de explotados en sus molinos harineros, en sus canteras de cemento y en otras fábricas por él controladas, ganándose el odio del pueblo" ("Parte de guerra del ERP", fuente original incluida en El terrorismo en la Argentina, Buenos Aires, Poder Ejecutivo Nacional, 1979, p. 261). Sin embargo, debería tenerse en cuenta que otro integrante de la familia Minetti, José Antonio, había matado a un integrante del ERP, Claudio Ludueña, en momentos en que este último "se aprestaba a expropiar un auto para utilizarlo luego en la guerra revolucionaria". José Antonio era el propietario del auto. El hecho tuvo lugar el 27-04-74 y el ERP lo denunció en Estrella Roja. Es probable que se haya tenido en cuenta este antecedente en la determinación del "ajusticiamiento" de Héctor Minetti, ocurrido dos años después. Las citas corresponden a Estrella Roja (s/f), Colección Documento Histórico No 25 de Infobae, p. 12.

29 In Memoriam, tomo 3, p.421.

30. In Memoriam, tomo II, p. 225.

31 In Memoriam, tomo III, p. 458. 
ceso de desarticulación organizativa) y aún en el marco de una "guerra de aparatos" resulta pertinente atender a la dimensión emotiva involucrada en las mismas. Clausurados los canales de la acción colectiva, ante la aceleración de las "caídas" (con el consiguiente sentimiento de derrota) y la constatación cotidiana de la complicidad de las empresas en prácticas represivas hasta entonces inéditas, se erigió la acción directa radical como uno de los únicos antecedentes de las prácticas partidarias que habían sido parte de una identidad y a los que aún era posible apelar. Gesto final de una impotencia y, también, del cumplimiento de un compromiso de sangre "con los compañeros caídos" tan propio de la militancia revolucionaria. Es probable, entonces, que estos sentimientos, sumados a un "odio de clase" en el que la retórica partidaria no había cesado nunca de insistir, hayan constituido el motor de este último impulso "ajusticiador".

\section{B: REPRESORES}

Entre marzo de 1972 y enero de 1977 el ERP ejecutó entre 20 y 34 integrantes de las fuerzas represivas ${ }^{32}$. La mayoría de esas ejecuciones constituyó la represalia perretista a la tortura, asesinato y desaparición de militantes por parte de las Fuerzas Armadas y de las policías provinciales y federal (y un caso de un infiltrado del Servicio de Inteligencia del Ejército). Por su número y su regularidad y, desde la óptica del ERP, por representar la determinación implacable de no negociar la sangre de los caídos (figura central del imaginario guerrillero) éstas fueron las ejecuciones por excelencia de la justicia perretista.

Si bien la tortura a prisioneros no era una práctica nueva en Argentina (y en el caso de los prisioneros políticos se constata su uso por lo menos desde 1930), lo cierto es que durante la dictadura instaurada en 1966 la tortura a prisioneros políticos y especialmente el uso de la picana eléctrica se generalizó al punto de quedar prácticamente institucionalizada. Lo mismo puede decirse del tercer gobierno peronista,

\footnotetext{
32 Ver cuadro página 4. En este apartado se considerarán exclusivamente los casos "A".
} 
principalmente a partir de 1974, cuando comenzó a intensificarse el accionar represivo ilegal. Los esfuerzos de los familiares de presos políticos y de sus abogados defensores (en uno y otro período) se concentraron, precisamente, en aquellas estrategias que pudieran al menos detener y limitar la tortura. Antecedentes similares se registran en el caso de asesinatos y fusilamientos de opositores y prisioneros políticos que, sin ser novedosos, alcanzaron en este período índices sin precedentes.

En el universo de sentidos implicados en el imaginario guerrillero, el del militante fue un cuerpo destinado al servicio de la revolución ("una persona entregada de cuerpo y alma a la revolución", alentaba el mandato partidario). Pero era la imagen de una muerte bélica, la del arrojo en el fulgor de una batalla o la de una valiente resistencia, en fin, la caída en combate, aquella convocada tanto por la retórica colectiva como por ese mundo íntimo de valores, expectativas y temores que conformaban la subjetividad del militante. Los vejámenes y el deshonor de la tortura, el asesinato a sangre fría que robaba para siempre la posibilidad de aquella otra muerte, aunque en parte reparados luego por la glorificación de héroes y mártires de la iconicidad partidaria, constituían las más graves de las ofensas a la dignidad revolucionaria; y por tanto sólo podían admitir, en nombre de otra moral, el máximo de los castigos: la pena de muerte.

La represalia del ERP a integrantes de las fuerzas represivas por la tortura, asesinato y desaparición de militantes asumió dos modalidades distintas: una personalizada y otra indiscriminada. La primera fue aquella por la cual se individualizó y ejecutó a los responsables directos de los crímenes mencionados. La segunda, en cambio, recayó indistintamente sobre miembros de una determinada fuerza, en tanto tales: a través de estas ejecuciones no se castigaba al individuo en sí sino a la institución de la que formaba parte.

Las personas "ajusticiadas" en virtud de su responsabilidad o culpabilidad directa en la tortura y/o asesinato de militantes fueron:

- Comandante Principal Abel P. Agarotti, ex jefe de la Policía de Tucumán al momento de su ejecución, ocurrida el 17-03-72. La justicia perretista lo condenó por tener "a su cargo directo la más salvaje represión y tortura contra nuestros hermanos tucumanos, encarce-

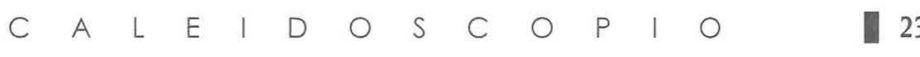


ló obreros, estudiantes y todos aquellos que levantaban su voz de protesta contra el régimen y su política de hambre y miseria"33.

- General Juan C. Sánchez, jefe del II cuerpo de Ejército, ejecutado el 10-04-72. Sánchez fue declarado culpable por haber propiciado "en toda la zona bajo su influencia, la instalación del más bárbaro régimen de tortura contra los combatientes populares de que se tenga noticia" 34

- Hugo G. Tamganini, inspector general de la Policía de Tucumán (sin fecha de ejecución). Tamagnini fue considerado "responsable de crímenes y de la tortura de numerosos militantes de nuestra organización, de organizaciones hermanas y de estudiantes y obreros [...] Responsable también de la represión al pueblo durante las mo vilizaciones" ${ }^{\prime 35}$.

- Carlos H. Juncos: había sido miembro de la División de Informaciones de la Jefatura de Policía Provincial de Córdoba. Fue ejecutado el 11 09-73. En la declaración correspondiente se denuncia: "este sanguinario personaje que torturó en la policía a numerosos revolucionarios que durante la dictadura cayeron prisioneros, ya hace mucho tiempo atrás había sido sentenciado por la justicia popular"36

- Suboficial (re) Mario Reduto, secuestrado el 22-02-74 y ejecutado presumiblemente el 13-03 del mismo año. Reduto "fue puesto a disposición del Tribunal Revolucionario por estar acusado de graves cargos que atentan contra la clase obrera y el pueblo. Estos cargos son: 1) Jefe del comando parapolicial; 2) Torturador; 3) Cómplice del secuestro y tortura a un combatiente caído en Azul ${ }^{37}$ [...] y 4) Partícipe a los allanamientos al pueblo del Zárate...."38

"Para los ojos del pueblo NO HAY ESCONDITES", en Estrella Roja, marzo/abril de 1972, p. 8

34 "El largo brazo de la justicia popular", en De Santis, A vencer o morir. PRT-ERP documentos tomo I, Buenos Aires, Eudeba, 1998, p.317.

35 "El pueblo castiga a sus torturadores" en Estrella Roja No 23, 15-08-73, pp.6-7

36 Estrella Roja ํo 26, 20 1 1 73, Colección Documento Histórico № 3 de Infobae.

37 Localidad de la provincia de Buenos Aires, sede de un regimiento militar asaltado por el ERP en enero de 1974.

38 "Comando Parapolicial Secuestrado" en Estrella Roja No 31, 04-03-74, Colección Documento Histórico $N^{\circ} 28$ de Infobae. 
- Cabo Rubén O. San Juan, ejecutado el 4-09-74. No se han encontrado fuentes de la ejecución pero el ERP lo había sentenciado a muerte en julio de 1973. Esta sentencia tuvo lugar tras la detención por parte del ERP de un ex oficial de policía, Jorge Colombo, el 17-07 de ese año. Colombo debía "rendir cuentas" ante el tribunal perretista por el "secuestro y posterior asesinato del compañero Ángel Brandozza". En su declaración Colombo afirmó que habían sido Rubén San Juan y dos oficiales (Marcelo Olazagoita y Grande) los responsables de aquellos hechos. Fue a raíz de esa declaración que el ERP comunicó su decisión de "AJUSTICIAR A LOS CRIMINALES POPULARES GRANDI, SAN JUAN Y OLAZAGOITA" ${ }^{39}$

- Comisario Eudoro Ibarra, ejecutado el 20-09-74 (junto con quien estuviera acusado de ser su cómplice, Héctor Zaraspe, taxista). Ibarra y Zaraspe habían sido identificados como los responsables directos de la tortura y asesinato de un combatiente del ERP. En la declaración que anuncia estos ajusticiamientos leemos: "Cuando la Compañía de Monte Ramón Rosa Jiménez tomó el nombre del inolvidable "Zurdo", estaba siempre caliente en nuestra memoria su salvaje asesinato en manos de la policía de Santa Lucía. El viernes 20 de septiembre a las 20:30 la Unidad de Monte copó Santa Lucía y cumplió la sentencia contra Eudoro Ibarra y Héctor Oscar Zaraspe, ambos declarados culpables por un tribunal revolucionario de las torturas y posterior asesinato del combatiente del pueblo Ramón Rosa Jiménez" 40

- Jesús Rainer (alias el Oso) "agente confeso del Servicio de Inteligencia del Ejército infiltrado en nuestra organización", ejecutado el 13-01-76. Este fue un "ajusticiamiento" excepcional puesto que a través de él no sólo se penaba la responsabilidad directa de Rainer en la muerte y desaparición de militantes sino también uno de los delitos más severamente castigados en todo grupo militar: la traición. Rainer, además, de provocar con su delación la "caída" de varios

39 Estrella Roja No 23, 15-08-73, pp. 7-9

40 "Santa Lucía. Potrero de las Tablas-Justicia Revolucionaria" s/f, fuente original incluida en El terrorismo en la Argentina, Poder Ejecutivo Nacional, 30 de noviembre de 1979, pp. 127-128. 
militantes durante los meses de noviembre y diciembre de 1975, fue quien informó al Ejército sobre los preparativos del asalto al cuartel de Monte Chingolo. "Detenido" y juzgado por el tribunal partidario, Ranier confesó "ser miembro del SIE infiltrado en el ERP con el objeto de destruir su organización. Ser responsable de la muerte y/o desaparición de más o menos 100 compañeros". Tras su condena y ejecución el ERP declaraba: "el cumplimiento de la sentencia de muerte dictada por el tribunal Partidario, ha puesto punto final a los crímenes del traidor. La justicia revolucionaria ha actuado descargando todo el peso de su fuerza sobre quien se atrevió a realizar actividades contrarrevolucionarias dentro de la organización. La justicia revolucionaria ha vengado a las decenas de compañeros muertos y desaparecidos y es un ejemplo y una advertencia..." ${ }^{41}$

En cuanto a la segunda modalidad de represalia, la indiscriminada, es posible afirmar que fue declarada por el ERP en dos oportunidades y llevada a cabo al menos en una.

La primera de ellas tuvo lugar en septiembre de 1974. El ERP había intentado asaltar, en agosto de ese año, el Regimiento 17 de Infantería Aerotransportada de Catamarca. El asalto no llegó a concretarse puesto que los guerrilleros fueron denunciados precipitándose entonces varios enfrentamientos con la policía provincial y el Ejército. Un grupo de guerrilleros logró huir; otro, integrado por 14 combatientes, se rindió. Sin embargo, nunca aparecieron con vida. Días después, en una conferencia de prensa, el ERP anunció que habían sido fusilados y que "esa acción fue deliberada e inspirada en el salvaje principio de que 'el ejército no toma guerrilleros prisioneros' [...]. El Comité Central [...] tomó una grave determinación. Ante el asesinato indiscriminado de nuestros compañeros, nuestra organización ha decidido emplear la represalia. Mientras el ejército opresor no tome guerrilleros prisioneros, el ERP no tomará oficiales prisioneros, y a cada asesinato responderá con una ejecución de oficiales indiscriminada. Es la única forma de

41 "Ajusticiamiento de un traidor" en El Combatiente No 200, 21-01-76, en De Santis, op.cit. tomo II, pp. 517-520. El Combatiente era el órgano de propaganda del PRT. 
obligar a una oficialidad cebada en el asesinato y la tortura, a respetar las leyes de la guerra"42.

Entre la publicación de esta "grave determinación" y los tres meses siguientes el ERP ejecutó, como respuesta a los fusilamientos de sus combatientes en Catamarca, a nueve oficiales del Ejército. Durante el desarrollo del operativo del último "ajusticiamiento" la hija menor del oficial ejecutado, de tres años de edad, resultó muerta y su hermana, de cinco años, gravemente herida. Aunque no se hayan encontrado declaraciones partidarias públicas al respecto, la memoria militante afirma que a raíz del trágico saldo inesperado el ERP puso fin a esta represalia indiscriminada (y, en efecto, no se registraron en los meses siguientes ejecuciones de integrantes de las fuerzas represivas).

Sin embargo, en agosto de 1975 y a pocos días de haber propuesto un armisticio el ERP declaró una segunda represalia de este tipo. La misma fue anunciada el 12 de agosto en una conferencia de prensa y publicada en Estrella Roja hacia finales de mes. Como si la represalia del año anterior hubiera sido en algo efectiva en su propósito normativizador ("obligar a respetar las leyes de la guerra"), esta nueva determinación volvía a encontrar su fundamento en la intensificación del accionar represivo ilegal y el agravante de la incipiente generalización de un fenómeno que en lo sucesivo no haría más que incrementarse, el de la desaparición de militantes. Esta vez, se advertía, la justicia perretista recaería sobre el amplio conjunto de fuerzas involucradas en la represión.

Es muy probable que esta última represalia no se haya llevado a cabo. Ya sea por el alto índice de muertos, prisioneros y desaparecidos que a esas alturas registraban las filas perretistas, ya sea porque sus últimos esfuerzos militares se concentraran en el envío de nuevos combatientes al monte tucumano o en los preparativos del asalto al cuartel de Monte Chingolo lo cierto es, en todo caso, que parece registrarse una sola ejecución tras el anuncio de esta segunda represalia ${ }^{43}$.

42 "Declaración" en Estrella Roja № 40, 23-09-74, en De Santis, op. cit, tomo II, pp. 326-326. También en: Colección Documento Histórico No 19 de Infobae, p. 2.

43 La misma fue la del Comisario Alfonso Vergel, el 03-09-75. No se han encontrado declaraciones relacionadas. Según consta en In Memoriam "sería el ERP quien se adjudicaría el atentado, mediante el llamado realizado por una mujer a los medios de prensa y policiales" (In Memoriam, tomo II, p. 495.)

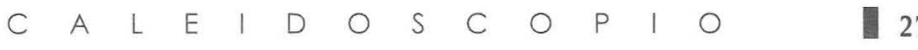


Finalmente, la última ejecución registrada que tuviera por víctima a un integrante de las fuerzas represivas, fue la del Vicecomodoro Roberto Echegoyen. Este caso, por la similitud de circunstancias en que se precipitó dicha ejecución, remite al de Sallustro.

Tras haber secuestrado a Echegoyen el 29-04-76, el ERP ofreció canjear su libertad "por uno de los siguientes compañeros prisioneros del enemigo: Edgardo Enríquez, miembro de la comisión política del MIR chileno, secuestrado por las fuerzas represivas el 10 de abril ${ }^{44} \mathrm{O}$ Juan Eliseo Ledesma, comandante del ERP y miembro del buró político, en manos del enemigo desde el 10 de diciembre de 1975"45

Se desconocen los pormenores de las negociaciones si es que éstas efectivamente existieron. De todas maneras, el desenlace de este caso se precipitó el 10-07-76 cuando el Ejército localizó la "cárcel del pueblo" donde Echegoyen permanecía secuestrado produciéndose un tiroteo en medio del cual Echegoyen fue ejecutado. Juan Eliseo Ledesma y Edgardo Enríquez continúan desaparecidos.

Se ha señalado anteriormente que aquellas realizadas en represalia por torturas y asesinatos de militantes fueron las ejecuciones por excelencia del ERP. En esa modalidad de la "justicia revolucionaria" esta organización recogía las experiencias de la llamada guerra de guerrillas en Latinoamérica, tanto en su variante rural como urbana. En ella, los "ajusticiamientos" parecían estar directamente identificados con las figuras del torturador y del traidor-delator. Por citar tan sólo dos ejemplos de amplia circulación e influencia en los grupos de la izquierda armada local, Régis Debray advertía que "la destrucción de un camión de transporte de tropas o la ejecución pública de un policía torturador hacen más propaganda efectiva entre la población vecina, propaganda alta y

44 Edgardo Enríquez era hermano de Miguel Enríquez máximo dirigente del Movimiento de Izquierda Revolucionaria (MIR) chileno, muerto en un enfrentamiento el 05-10-74 en Santiago, Chile. El MIR mantenía estrechos vínculos políticos con el PRT-ERP. Las dos organizaciones, conjuntamente con el Ejército de Liberación Nacional de Bolivia y el Movimiento de Liberación Nacional-Tupamaros, conformaban la Junta Coordinadora Revolucionaria (JCR) del Cono Sur.

45 "Parte de guerra. Detención de un vicecomodoro" en Estrella Roja s/nº, mayo de 1976, facsímil incluido en In Memoriam, tomo II, p. 221. 
profundamente política, que doscientos discursos"46. Por su parte, el brasileño Carlos Mariguella en su Minimanual del guerrillero urbano definía al "ajusticiamiento" como "la muerte de un espía norteamericano, de un agente de la dictadura, de un policía torturador, de una personalidad fascista del gobierno envuelta en crímenes y persecuciones de patriotas, de un chivato, delator, informante de la policía o un provocador policíaco" 47 La ejecución del torturador no sólo castigaba el martirio sufrido por los compañeros "en manos del enemigo"; era también la puesta en escena de una moralidad revolucionaria cuya voluntad de diferenciación con respecto a la de las fuerzas enemigas encontraba en la inadmisibilidad de la tortura uno de sus puntos nodales.

Las ejecuciones en castigo por el asesinato de militantes no fueron exclusivas del ERP y, dejando a un lado el accionar de otros grupos armados cuyos "ajusticiamientos" precedieron a los de esta organización, puede afirmarse que en el campo de las izquierdas aquella determinación reconoce un antecedente emblemático en el anarquismo de principios de siglo XX. Y resulta interesante observar que, aunque ajeno a la tradición anarquista, es precisamente ese antecedente aquel recuperado por el discurso perretista. En una Estrella Roja de octubre de 1974 (el año que concentra el mayor número de ejecuciones), en la sección permanente dedicada a la divulgación de acontecimientos históricos "ejemplares" (guerra de la independencia, guerra de Vietnam, revolución cubana, etc.) encontramos una reivindicación explícita de una práctica anarquista. En una nota titulada "El ajusticiamiento del Fusilador de la Patagonia" se extraía varios párrafos del libro de Osvaldo Bayer Los vengadores de la Patagonia Trágica que relataban, según palabras perretistas, "la heroica acción de Kurt Wilckens" el obrero anarquista alemán que matara al Teniente Coronel Varela, conocido como "el fusilador de la Patagonia"48.

46 Régis Debray, "¿Revolución en la revolución?" en Lucha Armada en la Argentina, año 1, No 1, Buenos Aires,2004, p. 133.

47 Carlos Mariguella, "Minimanual del guerrillero urbano" en Lucha Armada en la Argentina, año 1, № 2, Buenos Aires, 2005, p. 137.

48 "El ajusticiamiento del Fusilador de la Patagonia" en Estrella Roja No 41, 07-10-74, p. 7 . 
Más difícil pareciera haber sido la apelación a antecedentes de referencia en el caso de las represalias indiscriminadas, una medida verdaderamente excepcional para el universo revolucionario. También en el mes de octubre de 1974, en otro ejemplar de Estrella Roja se publicó un artículo titulado "Las represalias". En el copete del mismo se deja leer aquella búsqueda deliberada: "cuando el ERP resolvió responder a los sanguinarios fusilamientos de nuestros combatientes en Catamarca por parte del Ejército enemigo con la REPRESALIA INDISCRIMINADA [... tuvo en cuenta antecedentes internacionales que justificaban tan grave medida. Durante la Segunda Guerra Mundial el Ejército Soviético debió aplicar la represalia contra los Nazis, criminales de guerra de un salvajismo atroz"49. A continuación, el artículo reproducía un relato, seguramente fragmentado, de la ejecución de dos jerarcas nazis en la Ucrania ocupada de la segunda guerra. Es curioso constatar, sin embargo, que los hechos allí narrados no corresponden en absoluto a una represalia indiscriminada: dos integrantes de la resistencia deciden ejecutar a uno de los máximos jerarcas nazis de la ciudad y a su lugarteniente, comprobando luego de la ejecución que habían cometido un error "ajusticiando" a otros dos nazis en su lugar.

Con independencia de lo errático de la referencia, resulta sumamente significativo que el escenario escogido haya sido el de una guerra nacional y los "ajusticiados", integrantes de un ejército de ocupación. Es significativo porque la caracterización del proceso revolucionario que el ERP postulaba a partir de 1970 era el de "guerra revolucionaria" y en esa guerra la imagen que de su propio ejército construía a partir de los símbolos a los que apelaba, de su discursividad y, finalmente, de sus prácticas, era la de un ejército regular en oposición a otro ejército, también regular, que se asemejaba, cada vez más, a un ejército de ocupación.

\footnotetext{
49 "Las represalias" en Estrella Roja s/f, Colección Documento Histórico No 39 de Infobae, p. 8.
} 


\section{JUSTICIA REVOLUCIONARIA, VENGANZA Y GUERRA}

"El brazo de la justicia popular es largo y sabe ajustar cuentas con los asesinos y torturadores del pueblo"s0.

"Es la única forma de obligar a una oficialidad cebada en el asesinato y la tortura. a respetar las leyes de la guerra"51

"Ajustar cuentas" y "obligar a respetar las leyes de la guerra": es en el espacio configurado por estos vectores donde la ejecución perretista se erige como acto moralizador y normativizador.

El ajuste de cuentas es un acto de venganza, un castigo inmediato (sin mediaciones) que recibe en forma personalizada el perpetrador de un crimen. El sentido de este castigo es la restauración de un orden, de un equilibrio que aquel crimen ha roto o dañado: "la venganza funda el mundo, no lo desordena, sino que le devuelve el orden" ${ }^{25}$. El vengador restaura un equilibrio moral que nunca debió haber sido roto y, al mismo tiempo, normativiza lo que debe ser.

En su libro The Virtues of Vengeance ${ }^{53}$, Peter French establece las con diciones de una venganza virtuosa ("última esperanza de la moral" allí donde no existe un sistema de administración de penalidades adecuadas o donde éste es corrupto). Estas condiciones serían: la autoridad moral del vengador; la culpabilidad de quien es objeto de la venganza; la adecuación de la venganza a la ofensa; la acción menos en nombre de la víctima que de la comunidad moral; la imposibilidad de quien es objeto de venganza de comprender el mensaje si el castigo hubiera sido administrado por la justicia.

Del conjunto de estos componentes, aquellos en los que nos interesa hacer hincapié son la autoridad moral del vengador y la acción en nombre de la comunidad moral.

Estrella Roja No 93, 28-02-77, en: De Santis Daniel (2000), Tomo 2, p. 612.

51. Declaración leída en conferencia de prensa y reproducida en Estrella Roja No 40, 23-09-74. En: De Santis (2000), pp. 325-326. También en Colección de Documento Histórico de Infobae No 19, p. 2

52 Beatriz Sarlo (2003): La pasión y la excepción, Buenos Aires: Siglo XXI, p. 145

53 French, Peter (2001): The Virtues of Vengeance, USA: University Press of Kansass. 
El proceso de construcción identitaria de la militancia perretista estuvo fuertemente anclado en postulados y mandatos morales. Las distintas tramas de la discursividad partidaria, los símbolos y representaciones que poblaban su universo de referencias y los sentidos atribuidos a gran parte de sus prácticas confluían en un deber ser del revolucionario, condensado en la figura del hombre nuevo y matrizado por valores éticos morales ("solidaridad, humildad, sencillez, paciencia, espíritu de sacrificio $[. . . \mid \text { generosidad, amor al prójimo" })^{54}$ En la conjunción de su autoproclamado rol de vanguardia y en la insistencia y prosecución de estos valores, el PRT-ERP buscaba erigirse ante los movimientos de masas no sólo como referente político sino también como referente moral.

El tono de las declaraciones partidarias antes o después de cada ejecución y la connotación de las palabras empleadas ("crímenes", "atropellos", "fechorías", "verdugos del pueblo", "actos bárbaros", "siniestros personajes" $" 55$, etc.) dan cuenta de una profunda indignación moral, de una inaceptabilidad ética principalmente de las modalidades cruentas que había asumido la represión. Pero esta indignación no era presentada como propia o exclusiva del ERP; en rigor, era la "indignación popular"56 aquello que se expresaba a través de la palabra y el accionar perretista. Si, como afirma French, el vengador se siente unido de manera única y especial a la víctima del crimen castigado y por ella responde, lo hace en nombre de una comunidad moral, en este caso, de una justicia popular que, si bien encarna, lo trasciende. El ERP, integrado "por los mejores hijos del pueblo"57, era el "brazo

\footnotetext{
54 PRT (1972): "Moral y proletarización. Pequeña burguesía y revolución", PRT. s/f, p. 20

55 Éstas y otras expresiones similares se encuentran en prácticamente todas las declaraciones perretistas. Las citadas se extrajeron de los pronunciamientos del ERP tras los "ajusticiamientos" del Comandante Agarotti, Oberdan Sallustro y el General Sánchez.

56 "Para los ojos del pueblo NO HAY ESCONDITES" en Estrella Roja, marzo/abril de 1972, p. 8 (original, archivo Cedinci)

57 Fórmula acuñada para referirse a los integrantes del ERP
} 
ejecutor" de aquella justicia: "es por ello que el pueblo a través de su Ejército, el ERPy las demás organizaciones hermanas, ha comenzado a ejecutar el mandato popular y reprimir con la pena de muerte a todos los verdugos"58. Los asesinados eran los hijos del pueblo, la indignación era la del pueblo como también lo eran las "cárceles", los tribunales y las sentencias condenatorias. Refiriéndose al caso Sallustro: "el ERP interpretando los justos reclamos del pueblo, que pedía el castigo de este explotador, procedió a detenerlo en la cárcel del pueblo"; y en relación a la ejecución de Sánchez: "Nuestro Comando, conjuntamente con los de la organización hermana FAR, ejecutaron la sentencia que el pueblo le había impuesto. El explotador y el jefe de la represión fueron objetivos del mismo odio del pueblo. Su ejecución era un deseo de las masas; el ERP y la organización hermana FAR sólo fueron el brazo ejecutor de este sentimiento"59.

La autoridad moral que parecía arrogarse el ERP y en función de la cual vengaba los crímenes cometidos contra sus militantes y "contra el pueblo", no se sustentaba únicamente en la autoasignada representación de aquella justicia popular sustantiva; también encontraba otra fuente de legitimación en la postulación de una superioridad moral respecto de las fuerzas enemigas en la que el discurso partidario insistía con énfasis particular.

El trato otorgado hacia los prisioneros constituía la oportunidad por excelencia de hacer manifiesta aquella superioridad puesto que permitía el señalamiento -y la denuncia- del envilecimiento de la conducta enemiga en situación inversa. La liberación de prisioneros en frágiles situaciones de salud, la publicación de cartas y "confesiones" de prisioneros que hacían particular hincapié en el buen trato recibido se orientaban en aquella dirección.

En una resolución sobre la liberación de un coronel del Ejército, Florencio Crespo, que se encontraba "a disposición de la justicia popular", se explicaba que el detenido sufría de una enfermedad que de acuerdo al informe médico "no puede ser atendida eficientemente,

58 "El ERP al pueblo" en Estrella Roja, marzo/abril de 1972

59 "El largo brazo de la justicia popular" en De Santis, op.cit. tomo 1, pp. 316-317

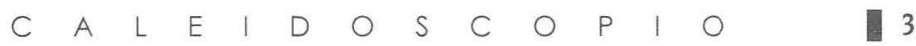


como corresponde en un correcto tratamiento a prisioneros de guerra", concluyendo que en tanto "este principio debe ser respetado y cumplido por los revolucionarios, a pesar de que las instituciones represivas de nuestra Patria $[\ldots]$ asesinan y torturan a nuestros compañeros [...] el estado Mayor Conjunto resuelve: 1) dejar en libertad al prisionero..." ${ }^{60}$.

En un artículo titulado "La moral y las tradiciones revolucionarias son respetuosas de la vida humana" 61 se relataban antecedentes históricos "ejemplares" de buen trato a prisioneros de guerra. Los ejemplos escogidos fueron los vietnamitas y el Gral Manuel Belgrano, quien durante la guerra de "nuestra primera independencia" dejó en libertad a un conjunto de prisioneros por no poder alimentarlos y asistirlos debidamente.

La apelación a estos ejemplos de conducta moral en tiempos de guerra es representativa del intento perretista de normativizar una confrontación entendida y caracterizada precisamente como guerra.

A partir del V Congreso del PRT (1970) la tradicional imagen insurreccional de la revolución comenzó a ser paulatinamente desplazada por la de la guerra. La propia fundación del ERP en aquel evento respondía a la convicción de que "la guerra civil revolucionaria ha comenzado en nuestro país" y esa guerra, se pronosticaba, "se irá transformando en guerra nacional antiimperialista" para culminar en un combate "contra

60 "Resolución № 252. Liberación del Cnel. Crespo" en Estrella Roja № 34, 27-05-74, Colección Documento Histórico No27 de Infobae, pág. 6. Otra determinación similar se tomaba y publicaba tras el secuestro de Alfred Laun ("Secuestro y liberación de Alfred Laun agente de la CIA. Parte de guerra" en Estrella Roja № 34, 27-05 74, Colección Documento Histórico №27 de Infobae, pág. 6). También en la misma dirección pueden citarse la carta del Tte Cnel Jorge Ibarzábal en la que insiste en el buen trato recibido (publicada en Estrella Roja No 31, 04-03-74) o en la "confesión" publicada de Jesús Ranier, en la que hace constar que "escribo esta declaración por propia voluntad y que no he recibido desde el momento de mi detención ni en ninguno de los interrogatorios, malos tratos ni torturas. Por el contrario, el trato ha sido firme pero correcto" ("Ajusticiamiento de un traidor" en El Combatiente No 200, 2-01-76)

61 En Estrella Roja No 34, 27-05-74, Colección Documento Histórico N²7 de Infobae, pp. 7-8. 
un enemigo invasor"62. Se trataba, en última instancia, de una guerra revolucionaria por "nuestra segunda y definitiva independencia"63. Y en esa guerra, el Ejército enemigo (que a los ojos del ERP había dejado de respetar el mundo de códigos compartidos de combate que toda guerra delimita) se fue convirtiendo en el principal sujeto interpelado. Con ese enemigo como referente el ERP fue construyendo, a partir de un movimiento casi especular, su propia identidad. Piénsese, por ejemplo, en el uso casi obligatorio y ceremonial del uniforme verde oliva que se impuso a los guerrilleros a partir de $1974^{64}$. La contrapartida de aquella identificación fue un movimiento de oposición y diferenciación sensiblemente anclado en la moral y, de ahí, en la insistencia normativizadora de la confrontación bélica.

La forma más usual de esa insistencia fue el reclamo del cumplimiento de las leyes de Ginebra, especialmente aquellas referidas al trato de prisioneros (al tiempo que la demostración de su cumplimiento fue el sustento imaginario de la propia autoridad moral ${ }^{65}$.

El 16-02-74, por ejemplo, el ERP exigió, mediante proclama pública, que se diera a conocer el estado en que se encontraban los militantes Jorge Antelo y Reinaldo Roldán, detenidos en el asalto al

62 "Resoluciones sobre dinámica y relaciones de nuestra guerra revolucionaria. Carácter de la guerra revolucionaria" en Resoluciones del V Congreso y Resoluciones posteriores. Pub. del PRT, 1971, p. 66

63 Fórmula acuñada en las proclamas del ERP.

64 Hacia fines de 1974, en coincidencia con el establecimiento del foco en Tucumán, el ERP resolvió "dar un importante paso en la construcción de las Fuerzas Armadas de la clase obrera y el pueblo". Dicho paso consistió en una mayor estructuración de las fuerzas guerrilleras mediante "el establecimiento de grados y la formulación de reglamentos...." ("Grados y Reglamentos en el ERP" en Estrella Roja [ंoctubre de 1974?], Colección Documento Histórico No 39 de Infobae, p. 14). Esta estructuración incluyó, además, el uso de uniformes e insignias propias de un Ejército regular.

65 Es interesante resaltar que en tanto los Protocolos Adicionales de Ginebra (que reglamentan los casos de conflictos armados dentro de las fronteras de un país incluyendo, por eso, a los ejércitos irregulares) se firmaron en 1977, aquellos a los que el ERP apelaba reglamentaban exclusivamente los conflictos bélicos entre Estados nacionales. 
regimiento de Azul y cuya situación se ignoraba. En aquella proclama se otorgaba al Ejército un plazo "de 48 horas, para responder sobre el estado en que se encuentran los compañeros [...] si no se registrara respuesta alguna, será ejecutado el Tte. Cnel. Ibarzábal, por recaer en su persona la responsabilidad de ser Jefe de la Institución Militar que viola los más elementales derechos humanos, negando los convenios internacionales firmados en Ginebra" 66 . Ibarzábal sería finalmente ejecutado el 19-11 de ese año en el transcurso de un traslado en el que fue interceptado el vehículo que lo transportaba "produciéndose un enfrentamiento que obligó a ajusticiar al detenido. [...] Debemos señalar que en todo momento nuestra organización procuró preservar la vida del detenido, teniendo en cuenta los principios humanitarios y las leyes internacionales [...] esta actitud ha sido demostrada permanentemente [...] Sin embargo, no ha sido igual el tratamiento que han recibido nuestros combatientes al caer en manos de las fuerzas contrarrevolucionarias" ${ }^{67}$

Las demostraciones de esta superioridad moral en el trato de prisioneros no tuvieron efecto normativizador alguno. Los guerrilleros no hicieron más que enfrentarse a una "oficialidad cebada en la tortura y el asesinato" y, en el escenario postulado de una confrontación bélica entre ejércitos regulares, respondieron al fusilamiento de sus combatientes en Catamarca con un castigo extremo -la ejecución- descargado, precisamente, sobre la oficialidad enemiga. A diferencia de un acto de venganza clásico en que el culpable de un crimen recibe de manera personal e intransferible el castigo que le corresponde, esta represalia

66 "Resolución del Estado Mayor del ERP" en Estrella Roja No 31, 04-03-74, Colección Documento Histórico de Infobae $N^{\circ} 28$, p. 13. En ese mismo ejemplar de la Estrella Roja se publicaba otro comunicado con fecha 17-02 en el que se anunciaba la suspensión de la ejecución de Ibarzábal puesto que el Ejército había respondido satisfactoriamente (quien habría actuado en dichas detenciones era la Policía Federal); en consecuencia, se advertía que: "se aplicará la justicia popular sin juicio sumario a la policía Federal y a sus organismos especializados en tortura" (p. 15). Un mes más tarde el FRP "ajusticiaría" al suboficial Mario Reduto.

67 "Parte de guerra, 20-11-74", original incluido en El terrorismo en Argentina, Poder Ejecutivo Nacional, 30 de noviembre de 1979, p. 322. 
indiscriminada asumió casi por reflejo las formas despersonalizadas de la guerra, coadyuvando al encarnecimiento general de la represión ${ }^{68}$.

\section{Justicia ReVolucionaria y teoría del Doble Poder}

"NO HAY UNA SOLA JUSTICIA, sino que frente a la IUSTICIA DE LOS EXPLOTADORES está la JUSTICIA DE LOS EXPLOTADOS..." "69

El ejercicio de una justicia revolucionaria y la autoequiparación del ERP con un ejército regular pueden considerarse expresiones de la llamada "teoría del doble poder" o "poder dual". Esta teoría (cuyos orígenes pueden ubicarse en la relación configurada de hecho entre los Soviets y el Gobierno Provisional de la Rusia revolucionaria entre febrero y octubre de 1917) no estuvo sistematizada por escrito en la historia perretista sino hasta septiembre de 1974, fecha en que Santucho la presentó al colectivo partidario en un escrito titulado Poder Burgués, Poder revolucionario.

La idea de poder dual postulaba un proceso de acumulación de poder sustentado en la disputa de órganos y funciones de poderes locales, entendidos éstos extraterritorialmente. Aseguraba Santucho en aquella oportunidad que "el camino para avanzar hacia la conquista del poder por medio de la insurrección armada general del pueblo argentino, pasa por el desarrollo del poder dual"70

68 Al año siguiente de estos hechos, en agosto de 1975, el PRT-ERP propuso un armisticio. A cambio de la liberación de todos los guerrilleros detenidos y de la derogación de la legislación represiva, especialmente aquella que ilegalizaba al ERP, la organización ofrecía la libertad del Mayor Larrabure, detenido por el ERP desde hacía un año. Pocos días después de la propuesta de armisticio se encontró el cadáver del Mayor Larrabure con signos de estrangulamiento. El ERP se apresuró a aclarar que "el Mayor Larrabure se suicidó [...]. Deslindamos toda responsabilidad respecto de este hecho ya que como es norma en nuestro Ejército el trato a los prisioneros de guerra siempre ha sido correcto respetando las Convenciones de Ginebra sobre estas cuestiones" (Estrella Roja No 59, 27-08-75, Colección Documento Histórico $N^{\circ} 7$, Infobae, p. 3)

69 Estrella Roja No 23, 15-08-73, p. 5.

70 Santucho, Mario (1974) Poder burgués, poder revolucionario, en www.marxists.org

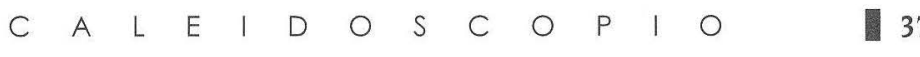


Con independencia de los debates en torno al "doble poder" que tuvieron lugar en el universo de izquierdas, consideraremos aquí las palabras de Luis Mattini, integrante del Buró político partidario. Afirma Mattini que si la imagen tradicional de la revolución social en los países industrializados había sido la de la insurrección armada, los procesos emancipatorios y revolucionarios asiáticos ofrecieron un nuevo modelo: el de un proceso prolongado, protagonizado por el campesinado, donde el poder se iba disputando palmo a palmo en dirección campociudad. Sin embargo, el caso argentino, con una preponderancia de población urbana, parecía no adecuarse completamente a ninguno de los dos modelos. De ahí, la apelación al concepto del poder dual: disputar el poder de la burguesía, no en sentido territorial, sino en el sentido de gobierno paralelo. En palabras de Santucho: "en el curso de la situación revolucionaria nace y se desarrolla el poder dual, es decir que la disputa por el poder se manifiesta primero en el surgimiento de órganos y formas de poder revolucionario a nivel local y nacional, que coexisten en oposición con el poder burgués"71.

En el mencionado documento, Santucho postulaba que a partir de la coyuntura configurada tras la muerte de Perón (julio de 1974), la estrategia partidaria debía estar centrada precisamente en el desarrollo del poder dual. Era ésta la presentación de una estrategia en cuyo futuro desarrollo Santucho proyectaba las características que había asumido la experiencia soviética de 1917.

Sin embargo, Mattini afirma que esta idea, aunque de manera difusa y "no muy clara", estaba ya presente en la discursividad y la praxis militante desde los primeros tiempos del accionar del ERP. Agrega que hasta los operativos más corrientes de reparto de alimentos "expropiados" en barrios pobres tenían como objetivo "demostrar el ejercicio de hecho del poder dual, algo así como ir organizando una sociedad más justa desde las entrañas mismas de la sociedad de clase"72.

Si Mattini está en lo cierto, la apelación al ejercicio de una justicia "popular", paralela y enfrentada a la del régimen puede considerar-

Santucho, Mario (1974) op cit

72 Mattini, Luis (1996): Hombres y mujeres del PRT-ERP. De Tucumán a la Tablada, Buenos Aires: Ed. de la Campana, op. cit. p. 308. 
se como una de las manifestaciones tempranas de esa voluntad de construcción de un doble poder: presentarse ante los movimientos de masas como opción de poder real y revolucionario.

Las declaraciones públicas ante las primeras ejecuciones perretistas (abril de 1972) no sólo impugnaban el sistema judicial de la dictadura y denunciaban la complicidad de los jueces para con las prácticas represivas -especialmente la tortura-sino que anticipaban, a su vez, la noción estratégica de disputar las funciones de poder (en este caso la administración de justicia): "todo el pueblo sabe que aquí se tortura, los jueces no [...] ¿Así que no saben que el Ejército y la policía están para reprimir al pueblo? Entérense: el ERP y las demás organizaciones revolucionarias son el brazo armado del pueblo [...] Así se irán enterando quienes se hacen los desentendidos, porque ejecutaremos a los asesinos del pueblo, llevaremos a la cárcel a quienes lo explotan y persiguen. Desarrollando la guerra construiremos poco a poco la justicia del pueblo que reemplazará a la del régimen miserable."73

Esta impugnación de la justicia del régimen excedió la dimensión puramente declarativa. Los militantes del ERP procesados por el asesinato del Gral. Sánchez, por ejemplo, revocaron durante el juicio el poder de la defensa. Este gesto fue parte de la llamada estrategia de ruptura llevada adelante por los abogados defensores. Esta estrategia, tomada del jurista francés Jacques Vergés, defensor del Frente de Liberación Nacional argelino, se sustentaba sobre la impugnación de la legitimidad de las instancias que juzgan -y, por tanto, del poder que las inviste- y del derecho aplicable ${ }^{74}$. Uno de los abogados defensores en ese juicio señaló que el objetivo de dicha estrategia era "hacer del tribunal una tribuna de denuncia", apelar al alegato político como justificación de los hechos juzgados y revertir el proceso "convirtiendo

73 Estrella Roja No 12, marzo/abril de 1972, en De Santis, op. cit. tomo I pp. 315-316

74 En su obra Estrategias judiciales en los procesos políticos, el jurista francés proponía dos estrategias jurídicas para los procesos contra los rebeldes argelinos llevados adelante por tribunales franceses: la estrategia de ruptura y la de connivencia. A diferencia de la primera, la estrategia de connivencia consistía en ajustarse a los parámetros vigentes y hacer uso de los procedimientos jurídicos disponibles. 
al acusado en acusador y al acusador en acusado"75.

Es cierto que se trató de un acontecimiento excepcional que encontraba su fundamento jurídico en la inconstitucionalidad del tribunal actuante, la Cámara Federal en lo Penal de la Nación, creada por decreto a comienzos de 1970 para el juzgamiento de los llamados delitos subversivos ${ }^{76}$. No obstante su excepcionalidad era representativo de aquella impugnación a las funciones y órganos de poder por parte de una organización que proponía y ejercía de hecho una justicia paralela.

Pocos meses después del mencionado proceso, y ya durante el tercer gobierno peronista, el ERP ofrecía una definición de esa otra justicia sustantiva que despreciaba la formalidad procedimental de la del "régimen burgués" y que se fundamentaba menos sobre un conjunto de penalidades codificadas que sobre valores políticos y morales identificados con el pueblo y su autoproclamada vanguardia: "es justicia popular cuando somos nosotros, el pueblo, el que decide sobre cada uno de nosotros y nuestros hermanos y no como los jueces burgueses, que siempre condenan a los pobres y a los combatientes populares y dejan libres a los que roban el sudor del pueblo trabajador [...] a los que torturan y matan [...] Por eso a cada torturador, a cada explotador y traidor de nuestros sacrificios debemos hacerles juicios populares [...] y aplicarles todo el peso de la justicia popular. Para que sepan que sabemos defendernos, que sabemos que no hay una sola justicia, sino que frente a la justicia de los explotadores está la justicia de los explotados..."77

Aunque resultaría absurdo postular que el ERP logró constituir efectivamente órganos de poder paralelos (al estilo de los soviets) es probable, al menos, que el ejercicio de esta justicia abonara la con-

75 Entrevista realizada por la autora para el Archivo Oral de Memoria Abierta (15-1103).

76 Esta cámara tenía competencia en todo el territorio de la Nación. Su inconstitucional radicaba no sólo en que se trataba de una tribunal ad hoc sino en que, además, violaba la jurisdicción natural de los jueces.

77 "La justicia popular es la justicia de los explotados" en Estrella Roja No 23, 15-08-73, p. 5. 
vicción perretista de estar consolidando opciones de poder, "acumulando fuerzas" que servirían de base y condición para una anunciada insurrección de masas que coronaría el triunfo revolucionario.

El esquema de "desarrollo de poder dual" postulado por Santucho en 1974 (en coincidencia, justamente, con la instalación del foco guerrillero en Tucumán) hacía hincapié, también, en la dimensión geográfica. Allí, se advertía que la insurrección final del pueblo podía ser precedida por insurrecciones parciales en distintos puntos del país "que establezcan el poder revolucionario en una región o provincia, las denominadas zonas liberadas"78. Aunque el foco instalado en Tucumán no alcanzó nunca a consolidarse como "zona liberada" (es decir, como área geográfica efectivamente controlada y administrada por la guerrilla) lo cierto es que era ése precisamente el objetivo del ERP. En el control de ese territorio la organización creía encontrar un fundamento inapelable para ser reconocida internacionalmente como fuerza-estado beligerante y exigir, en consecuencia, la aplicación de las convenciones de guerra de Ginebra. Por el lugar que la "Compañía del Monte" ocupaba en las expectativas partidarias, resulta necesario observar las modalidades que asumió allí el ejercicio de la justicia perretista. Es probable que este ejercicio se sustentara sobre la voluntad de hacer visible ante la población local la presencia de un nuevo poder para, a partir de allí, emerger como opción real.

El 20 de septiembre de 1974 los guerrilleros realizaron allí sus primeras ejecuciones. Éstas también llevaron el sello de la venganza personalizada por la tortura y asesinato de un combatiente. Pero más importante, quizás, fue que las mismas asumieron la forma de una escenificación pedagógica del nuevo poder revolucionario que se pretendía instaurar. Eudoro Ibarra (comisario de la localidad de Santa Lucía) y Héctor Zaraspe (taxista), declarados culpables de las torturas y posterior asesinato del combatiente Ramón Jiménez $z^{79}$ fueron ajusticiados públicamente: "la unidad reunió a los pobladores de Santa Lucía y previa explicación de la sentencia Ibarra y Zaraspe fueron ajusticiados

78 Santucho, Mario R. (1974), Poder burgués, poder revolucionario

79 El relato partidario afirma que luego de haber sido torturado en la comisaría local, Jiménez fue atado al taxi de Zaraspe y arrastrado por el pueblo hasta su muerte. El hecho había ocurrido en octubre de 1972. 
frente a la más decidida aprobación del pueblo que desde largo tiempo pedía justicia al ERP por el crimen del Zurdito"80

Esta "decidida aprobación", cualquiera haya sido su real alcance y extensión, no resistió el embate del Ejército Nacional, cuya estrategia represiva inauguró la metodología del terror que se extendería más tarde por todo el país. En su intento por pulverizar todo apoyo a la guerrilla el Ejército actuó -valga la ironía- en una verdadera zona liberada, inaugurando 14 centros clandestinos de detención donde guerrilleros y presuntos simpatizantes fueron torturados y desaparecidos. Mientras tanto, las cada vez más menguadas filas del ERP en intento por sobrevivir y evitar la propagación de la delación, ejecutaron en forma ejemplar a quienes colaboraron con el Ejército.

Al igual que en los principales centros urbanos del país, el golpe de Estado de 1976 encontró a los guerrilleros de Tucumán militarmente derrotados y sin aquella "decidida aprobación del pueblo" con la que habían poblado su imaginario e impulsado su accionar. Y aunque puedan considerarse parte de una estrategia que confiaba en la posibilidad de construir un poder real muy probablemente los "ajusticiamientos" perretistas no hayan sido en absoluto ajenos a ese paulatino proceso de desaprobación, de fracaso y, finalmente, de derrota.

80 "Santa Lucía. Potero de las Tablas- Justicia revolucionaria", op.cit. 